\title{
Preface
}

As much as today's state legislators, officials, and bureaucrats are criticized in California - sometimes with just cause - the first generation of political and governmental leaders was even more vilified in its own day. Many of them, it turned out, were- like their fellow Argonauts—short-termers, more passionate about "making their pile" and heading back to where they had hailed from than they were about building a new community and polity. Addicted to party and factional infighting, giving and receiving patronage, and even on occasion fighting or dueling to redress petty slights or to get their way, California's "founding fathers" were roundly condemned for their corruption, low moral standards, and general lack of accomplishments. Meeting in the winter of $1849^{-50}$, the first body of representatives, for example, was widely ridiculed as the "Legislature of a Thousand Drinks." Nor did governors escape the representatives' ill repute. Contemporary historian Hubert Howe Bancroft criticized the first governor, Peter Burnett, as "too slow in action, too wordy in speech, too conservative for the period, and too prejudiced for the rapid changes taking place"; even Burnett described himself as having "feeble abilities ... [that] allowed me to accomplish so little for the state." Another early governor-John McDougal—the public labeled "that gentlemanly drunkard."

With a few exceptions, later historians have followed the lead of the state's first citizens. In historical accounts, the first politicians, to the extent that they are even discussed, are portrayed as self-interested, disengaged, racially prejudiced, and venal, or at best incompetent. As a result, historians treat pioneer California's government as generally ineffective in coping with the great challenges of rapid population growth and economic change. Most often, however, in the historical literature, the establishment of early government in the state is simply ignored.

The first major dissenter from this evaluation, the first to take the subject seriously 
and to examine the creative origins of state government, was Gerald D. Nash, the recently deceased major historian of the American West. Nash's pioneering work, State Government and Economic Development: A History of Administrative Policies in California, 1849-1933 (Institute of Governmental Studies, University of California, Berkeley, 1964), demonstrated that many Californians, like pioneers on all previous frontiers, demanded effective government to facilitate and regulate economic development. In response to pressures from groups in the state, early officials, often drawing on their political and administrative experiences from before they arrived in the new Golden State, met challenges creatively, if not without error. As a result, reasonably effective laws guiding economic development were passed and state agencies were founded and took on the great challenges of encouraging and regulating transportation systems, business, mining, agriculture, and the administration of the state's public lands. Implicit in the book was a revolutionary reinterpretation of early state government, but, although subsequent historians read and cited Nash's book, few of them took up his themes for further study and elaboration.

That is precisely what the scholars in the current volume, Taming the Elephant, propose to do. Discarding common preconceptions in analyzing politics, government, and law in California from 1846 through the adoption of the second state constitution in 1879 , the authors examine patterns of interest and politics, the inception of constitution, law, jurisprudence, government-agency formation, and public policy. In studying the building of what has come to be called "the public sector," the authors chart out the roles played by diverse groups-from criminals to peace officers, judges, and attorneys, from entrepreneurs to miners and farmers, from voters to elected and appointed officials, from defenders of traditional racial and gender oppression to emerging articulate women and African Americans. Along the way, some of these essays investigate subjects largely overlooked in the past, including the origin and significance in pioneer California of local and federal government, as well as civil rights for women and racial minorities.

All of this volume's authors discover ambiguity and contradiction: a body of civil rights achieved by oppressed groups, but evolving within a society that remained fundamentally racist and sexist; strengthening traditions of law, order, and social responsibility emerging in a population prone to self-aggrandizement, violence, and disregard of community values; enlightened laws passed by a legislature that refused to provide sufficient funds to enforce them; dedicated officials attempting to work for the general welfare while self-seeking, factionalism, and corruption still tainted public affairs; effective government coexisting with favoritism, inefficiency, and inequity. Nevertheless, workable forms of government took shape; nagging problems of settlement and economic development were addressed, even while some were ignored and worsened; and legacies were created for future Californians that have lasted to the present day. 
Taming the Elephant: Politics, Government, and Law in Pioneer California is the fourth volume in the California History Sesquicentennial Series, presented by the California Historical Society-the state's officially designated historical societyand the University of California Press, with the support of California State University, Hayward, and many other partners. Four topical, but interrelated, volumes, published beginning in 1998, reexamine the meaning, particularly from today's perspective, of the founding of modern California in the pre-I848 and gold-rush-era experiences. Each of the volumes collects essays by authors, drawn from the ranks of leading humanists, social scientists, and scientists, reviewing the best, most up-to-date thinking on major topics associated with the state's pioneer period through the r87os. The authors have been asked to consider, within their area of expertise, the general themes that run through all four volumes: the interplay of traditional cultures and frontier innovation in the creation of a distinctive California society; the dynamic interaction of people and nature and the beginnings of massive environmental change; the impact of the California experience on the nation and the wider world; the shaping influence of pioneer patterns on modern California; and the importance and legacy of ethnic and cultural diversity as a major dimension of the state's history.

The California History Sesquicentennial volumes have been published simultaneously as expanded issues of California History, the quarterly of the Historical Society, and as books for general distribution. Each volume has been co-edited by Richard J. Orsi, Professor of History (now emeritus), California State University, Hayward, and editor (now emeritus) of the quarterly, who has worked with a consulting editor who is a leading scholar in the specific field. Volume I in the series, Contested Eden: California before the Gold Rush, co-edited by Ramón A. Gutiérrez, Professor of Ethnic Studies and History, University of California, San Diego, and issued in 1997/98, dealt with the social, economic, cultural, political, and environmental patterns of Native American, Spanish, and Mexican California through 1848. Volume 2 in the series, A Golden State: Mining and Economic Development in Gold Rush California, co-edited by James J. Rawls, member of the history faculty at Diablo Valley College, and issued in 1998/99, examined the pioneer industry of gold mining, its inception and development, and its impact on the state, the West, and the national and world economies. Volume 3 in the series, Rooted in Barbarous Soil: People, Culture, and Community in Gold Rush California, co-edited by Kevin Starr, State Librarian of California, and issued in 2000, focused on the Gold Rush and the migration and settlement of peoples, cultures, organizations, and institutions. Volume 4, the present work, co-edited by John F. Burns, former California State Archivist and State Historian and currently history and social science consultant with the California Department of Education, investigates the inception of government and politics—statehood, early constitution-building, law, bureaucracy, and civil rights. 
The California Historical Society's issuing of these major sesquicentennial publications is made possible through the contributions of all the Society's members, as well as a host of direct and indirect supporters. Chief among the helping agencies are the University of California Press, the California State Archives, California State University, Hayward (which until 200I furnished support for editing the quarterly and these special issues), Loyola Marymount University (Los Angeles), the California Supreme Court Historical Society, the Foundation of the State Bar of California, and the Mericos Foundation of South Pasadena, which has provided a generous grant specifically for the Sesquicentennial Series.

Many individuals have also shared their time, knowledge, energy, and resources. The Historical Society's particular appreciation goes to Executive Directors emeriti Michael McCone and Michael Duty, whose dedication to the Society, faith in its quarterly, and executive ability made this series possible; Lynne Withey, Director of the University of California Press, who has been an indispensable part of the Sesquicentennial History project from inception to completion; Mrs. Johan Blokker of the Mericos Foundation, whose belief in the project has been critical to its success; John F. Burns, co-editor of this volume, who from the beginning of the series was an important contributor to the conceptualization of this volume and whose unique perspective as the major historian of California's state government has added immeasurably to the quality of its contents; Dr. Janet Fireman, Editor of California History, who picked up the torch on the Sesquicentennial Series and graciously shepherded this volume through to completion; Dr. Norma Rees, President, and Dr. Frank Martino, Vice President and Provost, California State University, Hayward, who have provided generous assistance for the Sesquicentennial Series and the general editing office of California History; Dr. Henry Reichman, Chair, Department of History at California State University, Hayward, as well as other history colleagues, who during the publication of each of the sesquicentennial volumes, as in all the issues of the quarterly, made available the magnificent resources and staff of the department to encourage and assist the quarterly; Dr. Kevin Starr, State Librarian of California and preeminent scholar of California culture, whose enthusiastic support of the California History Sesquicentennial Series project when he was a Trustee of the California Historical Society and chair of its Publications Committee was indispensable to the development of the series, as well as of volume 3 specifically; Joshua Paddison and Teena Stern, insightful historians and illustrations editors of this volume, who discovered, edited, and captioned a magnificent set of images, in many cases never before published; Marlene Smith-Baranzini, historian, author, associate editor of California History, and true partner in every facet of this volume, this series, and all other undertakings of the quarterly; and Anthony Kirk, cultural historian and expert on California iconography, who has for a decade served as an invaluable consultant and friend of the quarterly on the history of art and photog- 
raphy and many other subjects of which he is a master. Other important contributors included our sharp-eyed assistant editors Joshua Paddison, Peter Orsi, and Zac Baranzini; Liz Ginno, historian and member of the library faculty at California State University, Hayward; and Larry Campbell, Patricia Keats, Jennifer Liss, Scott Shields, Emily Wolff, Bo Mompho, Judith Deaton, Tanya Hollis, and other members of the loyal, dedicated, and professional staff of the California Historical Society, San Francisco.

Our thanks also go to all the individuals and institutions who made it possible to use images from their collections in this work or who provided other assistance. Many of the following not only participated in important ways in the preparation of this volume, but have served as friends and invaluable resource persons over years of California History's publications. Although space precludes listing all their names, special mention should be made of Dace Taube, Curator, Regional History Collections, Doheny Library, University of Southern California, who served, as always, as a knowledgeable and generous adviser on illustrations for the quarterly; Peter Blodgett and Jennifer Watts, the Huntington Library; Jeff Crawford, Placer County Department of Museums; Jack von Euw and Susan Snyder, the Bancroft Library; Ellen Harding and Gary Kurutz, the California State Library; Genevieve Troka, California State Archives; Diane Curry, the Oakland Museum of California; Pat Johnson, Sacramento Archives and Museum Collection Center; Mary Haas, Fine Arts Museums of San Francisco; Vito Sgromo, California State Capitol Museum; and Peter E. Palmquist of Arcata, California, photographer, photography collector, and, of course, the leading historian of photography of the American West.

One final debt needs acknowledgment: there can be no more talented, exacting, resourceful, dedicated, and collegial an editor than Kathleen MacDougall, our project editor at the University of California Press, who has now guided and speeded the production of the last three volumes of the Sesquicentennial Series.

\section{Stephen Becker}

Executive Director,

California Historical Society

Richard J. Orsi
Professor of History (Emeritus),
California State University, Hayward,
and Editor (Emeritus), California History 
This page intentionally left blank 